\title{
Effects of dietary L-threonine and Saccharomyces cerevisiae on performance, intestinal morphology and immune response of broiler chickens
}

\author{
V. Rezaeipour ${ }^{\#}$, H. Fononi \& M. Irani \\ Department of Animal Science, Qaemshahr Branch Islamic Azad University, Qaemshahr, P.O. Box 163, Iran \\ Copyright resides with the authors in terms of the Creative Commons Attribution 2.5 South African Licence. \\ : http://creativecommons.org/licenses/by/2.5/za \\ Condition of use: The user may copy, distribute, transmit and adapt the work, but must recognise the authors and the South African \\ Journal of Animal Science.
}

\begin{abstract}
The objective of this study was to investigate the effects of four dietary levels of L-threonine $(0,2.5,5$ and $7.5 \mathrm{~g} / \mathrm{kg}$ ) with or without Saccharomyces cerevisiae (SC) on performance, carcass characteristics, intestinal morphology and immune system of broiler chickens. A total of 360 1-d-old male broiler chicks were randomly allocated to eight treatments with three replicates of 15 birds. The experiment was done at 0 to 3 weeks (as starter phase) and 3 to 6 weeks (as grower phase). Growth performance traits including weight gain, feed intake and feed conversion ratio were recorded at the end of each week. At the end of the experiment eight birds per treatment were killed and carcass analysis was done. Sampling for blood evaluation was done on 7, 28 and 42 days of age. Results of this study indicated that use of SC did not affect feed intake, weight gain and feed conversion ratio in chicks in contrast with the L-threonine. Use of L-threonine improved feed conversion ratio and gain of birds. Carcass traits were not influenced by dietary L-threonine and SC supplements. Use of L-threonine increased the intestinal morphology parameters such as crypt depth and villi height and width in both jejunum and ileum segments. On the other hand, villi height and width and crypt depth increased in both jejunum and ileum segments when dietary L-threonine increased. Effect of SC supplement on intestinal morphology was not significant. Results of CBC (cell blood counts) parameters, such as white blood cells, red blood cells, haematocrit and haemoglobin showed that these parameters were not affected by dietary treatments. Furthermore, the immune response (antibody titre) against Newcastle disease was not affected by SC on both 26 and 42 days of age. However, use of L-threonine influenced the chicks' immune response at 42 days of age. Our results have shown that the supplementation of L-threonine as a source of dietary-threonine in combination with SC improved growth performance and intestinal morphology traits in broilers.
\end{abstract}

Keywords: Feed additive, growth, gut characteristics, bird

\#Corresponding author: Vrezaeipour@gmail.com

\section{Introduction}

Threonine is the third most limiting amino acid in broiler diets, especially in a low crude protein diet. L-threonine is added to the diet of pigs and poultry in order to exactly match the dietary amino acid balance to the unique nutritional requirements of the animal (Mikail et al., 2006). There are many reports on the threonine requirements of poultry (Rosa et al., 2001; Shan et al., 2003; Ahmadi \& Golian, 2010), but less information is available on the effects of dietary L-threonine on the immune system and intestinal morphology of broilers. Threonine is involved in important metabolic processes such as uric acid formation and protein synthesis. Also, poultry are not capable of synthesizing threonine de novo which makes it a nutritionally essential amino acid. Dozier et al. (2001) indicated that broilers fed inadequate threonine had decreased live performance, but no effect was apparent on carcass fat. It has been reported that threonine is an important component of mucus (40\% of protein in mucus glycoproteins) in the digestive tract (Carlstedt et al., 1993). Most parts of mucins are not digestible and the associated threonine cannot be recovered (Fuller, 1994). Therefore, it is necessary to balance threonine in broiler diets by adding L-threonine supplementation or use of soybean meal and meat meal as most important ingredients which supply threonine in the chick diet. 
Antibiotics have long been used as a feed additive to increase broiler's growth performance and control of disease (Chen et al., 2009). Use of products such as probiotics, prebiotics and organic acids as replacements for antibiotics have increased in recent times. Probiotics act by competitive exclusion, lower gut $\mathrm{pH}$, produce bacteriocins, lysozyme and peroxides, and stimulate the immune system (Grashorn, 2010). Some of the probiotic products available on the market contain Sacharomcyces varieties. Saccharomyces cerevisiae (SC), one of the most widely commercialized types of yeast, has long been fed to animals. Kanat \& Calialar (1996) demonstrated that active dry yeast increased weight gain without affecting feed conversion ratio in broiler chicks. In contrast, some authors found that use of yeast cell in broiler diets improved feed conversion ratio (Onifade et al., 1999).

The objective of the current study was to examine the effects of dietary L-threonine in diets supplemented with SC on performance, carcass characteristics, intestinal morphology and immune response of broiler chicks.

\section{Materials and Methods}

Maize-soybean meal based diets (for the starter and grower periods) were formulated to meet or exceed the nutrient requirement for chickens recommended by the NRC (1994). The ingredient and calculated nutrients profile of the experimental diets are presented in Table 1 . The experiment was carried out in a completely randomized design with $2 \times 4$ factorial arrangement, including two levels of SC (0 and 5 $\mathrm{g} / \mathrm{kg}$ ) and four levels of L-threonine supplementation (0, 2.5, 5.0 and $7.5 \mathrm{~g} / \mathrm{kg}$ ). Each treatment was represented by three replicates and 15 male day-old chicks were randomly assigned to each pen. The birds were fed the eight experimental diets until the age of 42 days. Feed intake and body weight gain of each pen were measured at the end of each week. Feed conversion ratio for each pen was calculated by dividing feed intake by body weight gain. Mortality was recorded daily and feed consumption data were corrected for body weight of mortalities.

Two birds per replicate were bled via the wing vein at 26 and $42 \mathrm{~d}$ of age to determine the antibody production against Newcastle disease (ND). The first part of the blood sample (3 mL) was drawn and allowed to clot at room temperature $\left(18^{\circ} \mathrm{C}\right)$ for $2 \mathrm{~h}$ prior to collect serum. Serum was separated by centrifugation and stored at $-20^{\circ} \mathrm{C}$ for further analysis. The remainder of the blood sample $(2 \mathrm{~mL})$ was collected in tubes containing EDTA, and then analyzed for cell blood count (CBC) parameters.

At 42 days of age, eight randomly selected birds from each treatment were weighed and sacrificed. The weights of the intestinal tract (after digesta removal), breast, thigh, liver (without gallbladder) and abdominal fat were recorded and their weights (\%) relative to body weight were calculated.

Segments of the jejunum and ileum were excised for morphological evaluation. The intestinal segments were flushed clean with PBS (phosphate buffered saline) to avoid damage to the tissues. Then, samples were fixed in Clark solution for one hour. Samples were then transferred into $50 \%$ ethanol solution. A 0.5-cm section was then processed and embedded in paraffin, stained with eosin blue and examined with a light microscope. The 15 longest and straightest villi and associated crypts were measured in each segment.

Statistical analysis was carried out using a general linear model (GLM Procedure) to evaluate the effects of treatments on performance, carcass characteristics, intestinal morphology and immune system of broilers, using SAS (2001). Regression analysis was carried out on performance data. Statistical significance of differences among treatments was done using the Duncan's multiple range test at $(P<0.05)$.

\section{Results and Discussion}

Results of effects of dietary treatments on broilers performance are presented in Table 2. These findings indicate that effect of different inclusion rate of dietary L-threonine on broilers gain, feed intake and feed conversion ratio was statistically significant $(P<0.05)$. In general, increasing of L-threonine in diets improved feed conversion ratio and gain (Figures 1 and 3). In contrast, the effects of SC supplementation did not affect broiler performance parameters $(P>0.05)$. Results of carcass characteristics and internal organ weights of broilers are shown in Table 3 . These traits did not change significantly as a result of both dietary L-threonine and SC supplementation $(P>0.05)$. Effects of dietary treatments on intestinal morphology of broiler chicks are presented in Table 4. Results showed that the effects of dietary L-threonine on L-threonine on intestinal morphology were statistically significant $(P<0.05)$. 
Table 1 The ingredients and chemical composition of basal diets

\begin{tabular}{|c|c|c|}
\hline \multirow[b]{2}{*}{ Ingredients (\%) } & \multicolumn{2}{|c|}{ Basal diets } \\
\hline & Starter & Grower \\
\hline Maize & 61.21 & 66.00 \\
\hline Soybean meal & 33.15 & 28.00 \\
\hline Soybean oil & 1.70 & 2.49 \\
\hline Dicalcium phosphate & 1.36 & 1.11 \\
\hline Limestone & 1.44 & 1.44 \\
\hline Salt & 0.42 & 0.33 \\
\hline Mineral and vitamin premix ${ }^{1}$ & 0.50 & 0.50 \\
\hline DL-Methionine & 0.17 & 0.08 \\
\hline Anticoccidial & 0.05 & 0.05 \\
\hline \multicolumn{3}{|l|}{ Chemical composition (DM) } \\
\hline Metabolisable energy (MJ/kg) & 12.56 & 12.98 \\
\hline Crude protein $(\mathrm{g} / \mathrm{kg})$ & 215.6 & 194.3 \\
\hline Calcium (g/kg) & 9.4 & 8.7 \\
\hline Phosphorus, available (g/kg) & 4.0 & 3.40 \\
\hline Threonine (g/kg) & 8.0 & 7.20 \\
\hline Met+Cys (g/kg) & 8.50 & 7.10 \\
\hline Lysine (g/kg) & 11.4 & 10.0 \\
\hline
\end{tabular}

Table 2 The effect of dietary Saccharomyces cerevisiae (SC) and L-threonine on broilers gain, feed intake and feed conversion ratio (FCR)

\begin{tabular}{|c|c|c|c|c|c|}
\hline \multirow{2}{*}{\multicolumn{3}{|c|}{ Treatment }} & \multicolumn{3}{|c|}{ Parameters } \\
\hline & & & \multirow{2}{*}{$\begin{array}{c}\text { Gain } \\
\text { (g) }\end{array}$} & \multirow{2}{*}{$\frac{\text { Feed intake }}{\text { (g) }}$} & \multirow{2}{*}{$\frac{\text { FCR }}{\text { (g feed/g gain) }}$} \\
\hline L-threonine (g/kg) & SC & & & & \\
\hline 0 & & & $52.39^{b}$ & $100.13^{\mathrm{b}}$ & $1.83^{\mathrm{ab}}$ \\
\hline 2.5 & & & $53.93^{\mathrm{ab}}$ & $104.71^{\mathrm{a}}$ & $1.84^{\mathrm{a}}$ \\
\hline 5 & & & $54.44^{\mathrm{ab}}$ & $101.80^{\mathrm{ab}}$ & $1.78^{\mathrm{ab}}$ \\
\hline 7.5 & & & $55.00^{\mathrm{a}}$ & $102.61^{\mathrm{ab}}$ & $1.77^{\mathrm{b}}$ \\
\hline \multirow[t]{3}{*}{ SEM } & & & 0.75 & 1.05 & 0.02 \\
\hline & + & & 54.15 & 101.68 & 1.79 \\
\hline & - & & 53.72 & 102.95 & 1.82 \\
\hline SEM & & & 0.53 & 0.74 & 0.01 \\
\hline \multicolumn{6}{|l|}{ Interaction effect } \\
\hline L-thr $\times$ SC & & $P$ value & $>0.05$ & $>0.05$ & $>0.05$ \\
\hline
\end{tabular}




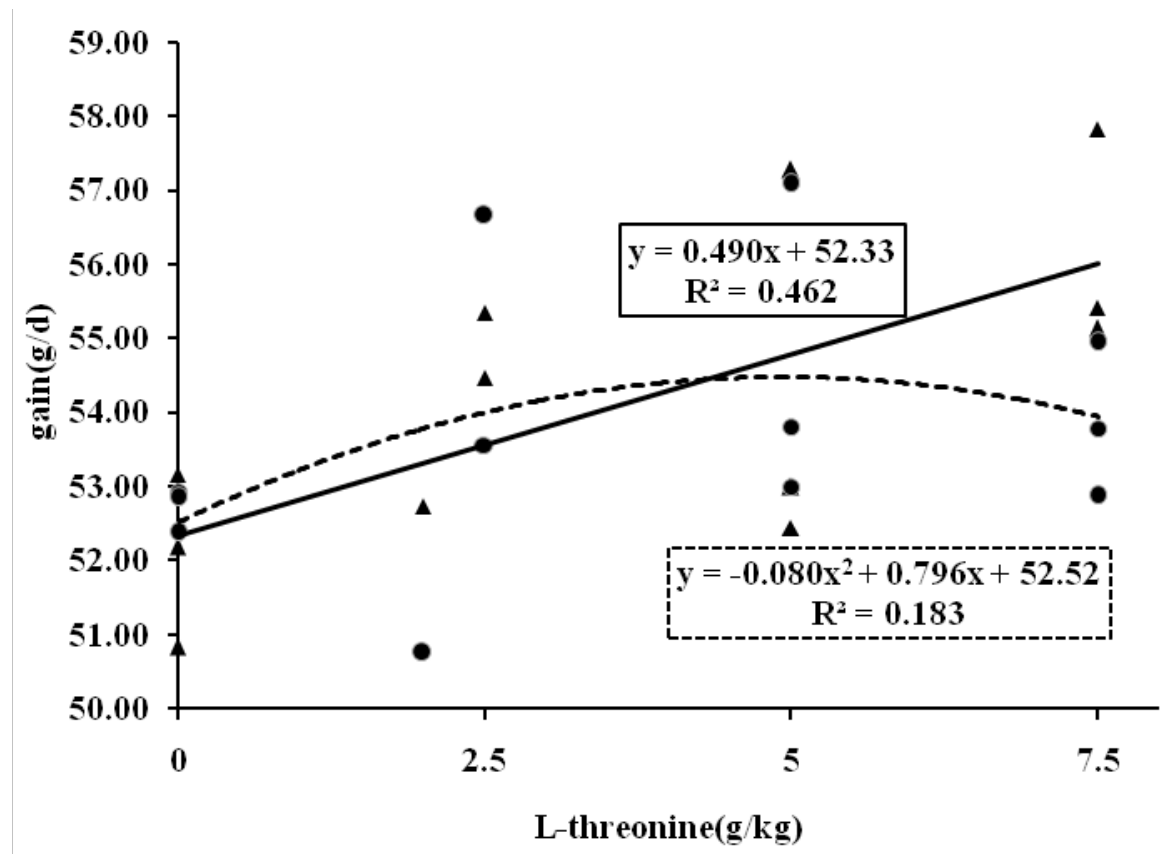

Figure 1 Regression equations for gain (g/d) of broiler chicks fed different levels of L-threonine and two levels of Saccharomyces cerevisiae, $0 \mathrm{~g} / \mathrm{kg}(\boldsymbol{\Lambda}-)$ and $5 \mathrm{~g} / \mathrm{kg}(\bullet---)$.

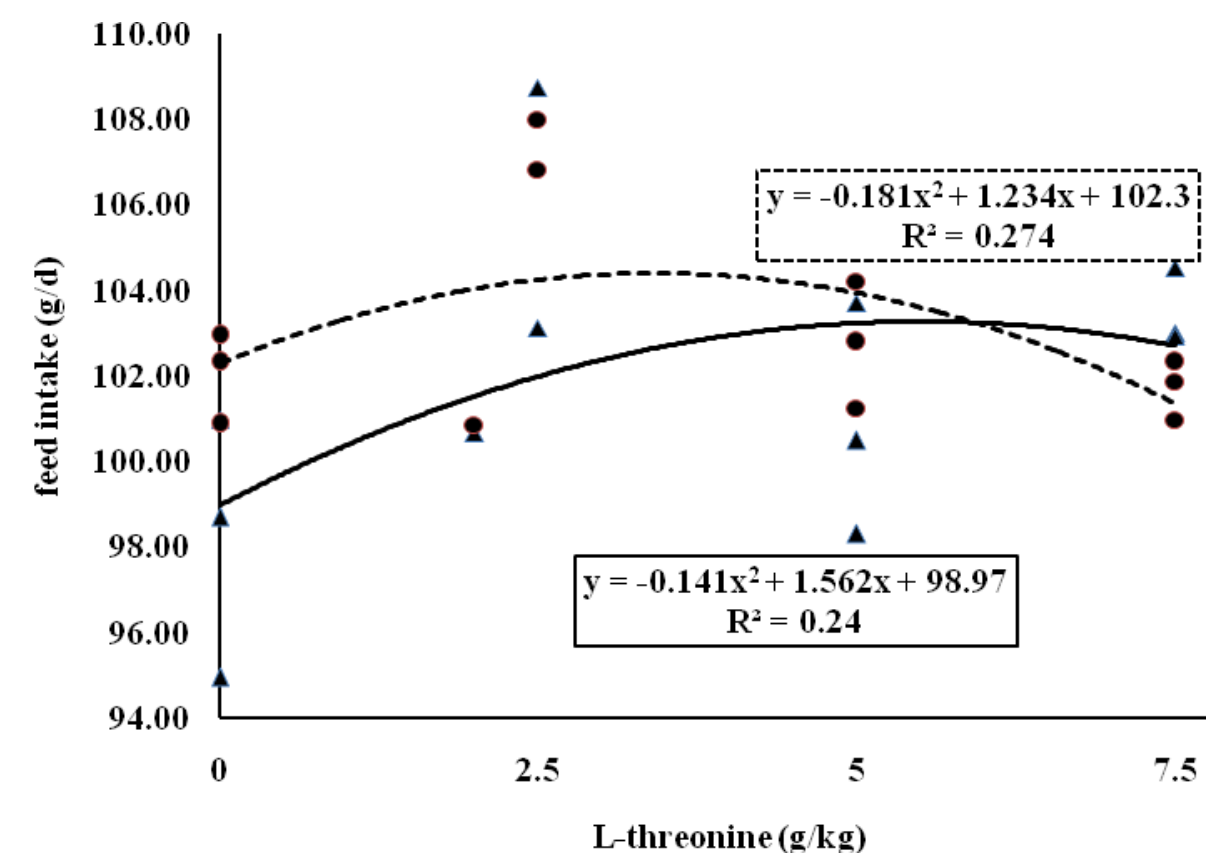

Figure 2 Regression equations for feed intake (g/d) of broiler chicks fed different levels of L-threonine and two levels of Saccharomyces cerevisiae, $0 \mathrm{~g} / \mathrm{kg}(\boldsymbol{\Lambda}-)$ and $5 \mathrm{~g} / \mathrm{kg}(\bullet---)$. 


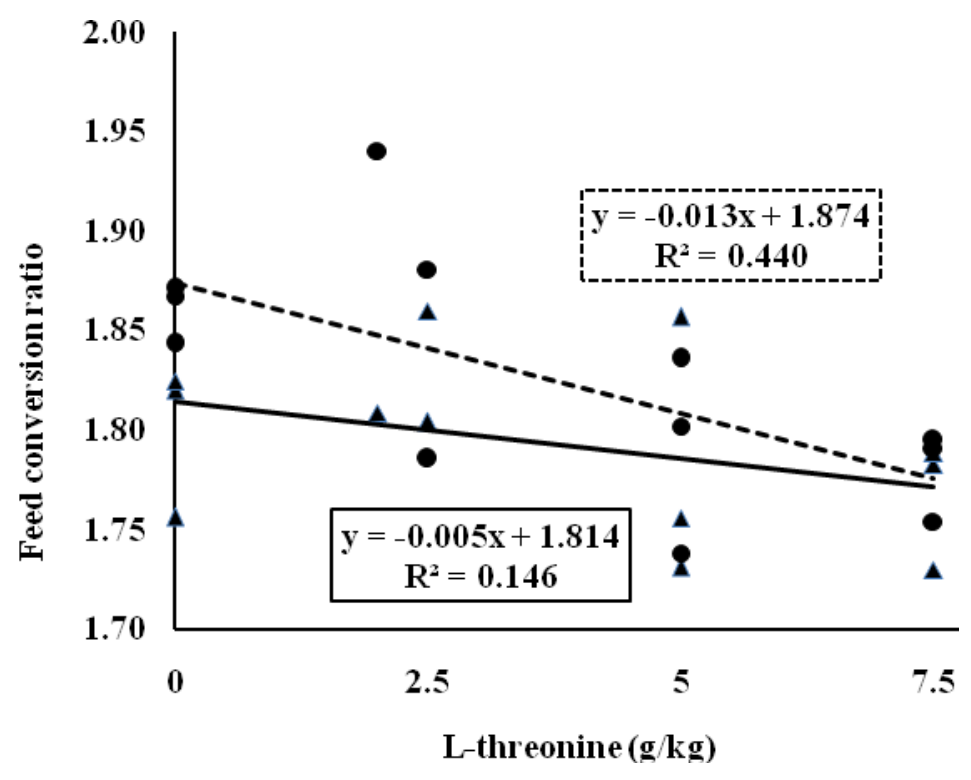

Figure 3 Regression equations for feed conversion ratio of broiler chicks fed different levels of L-threonine and two levels of Saccharomyces cerevisiae, $0 \mathrm{~g} / \mathrm{kg}(\boldsymbol{\Lambda}-)$ and $5 \mathrm{~g} / \mathrm{kg}(\bullet---)$.

Results indicated that with an increase of L-threonine inclusion rate in diets all intestinal parameters were increased. In contrast, SC supplementation did not affect broiler intestinal morphology $(P>0.05)$. The effects of dietary treatments on cell blood count and antibody titres against Newcastle disease are shown in Table 5. Results indicate that both dietary L-threonine and SC did not affect cell blood count of broilers $(P$ $>0.05)$. Except for an effect of L-threonine on antibody titre at 42 days of age $(P<0.05)$, antibody titres against Newcastle disease were not affected by dietary treatments $(P>0.05)$ (Table 5).

Table 3 Effects of dietary Saccharomyces cerevisiae (SC) and L-threonine on carcass yield, abdominal fat and internal organs of broilers

\begin{tabular}{|c|c|c|c|c|c|c|c|}
\hline \multirow{2}{*}{ Treatment } & & & \multicolumn{5}{|c|}{ Parameters ${ }^{1}$} \\
\hline & & & \multirow{2}{*}{$\begin{array}{c}\text { Breast } \\
(\%)\end{array}$} & \multirow{2}{*}{$\begin{array}{l}\text { Thigh } \\
\text { (\%) }\end{array}$} & \multirow{2}{*}{$\begin{array}{c}\text { Abdominal fat } \\
(\%)\end{array}$} & \multirow{2}{*}{$\begin{array}{c}\text { Liver } \\
(\%)\end{array}$} & \multirow{2}{*}{$\frac{\text { Intestines }}{(\%)}$} \\
\hline L-threonine (g/kg) & SC & & & & & & \\
\hline 0 & & & 22.26 & 19.49 & 1.92 & 1.70 & 3.70 \\
\hline 2.5 & & & 23.48 & 19.21 & 2.31 & 1.77 & 4.05 \\
\hline 5 & & & 23.54 & 19.25 & 2.01 & 1.52 & 3.85 \\
\hline 7.5 & & & 23.67 & 19.22 & 1.77 & 1.62 & 4.54 \\
\hline \multirow[t]{3}{*}{ SEM } & & & 0.83 & 0.40 & 0.27 & 0.12 & 0.36 \\
\hline & + & & 23.73 & 19.83 & 2.10 & 1.73 & 3.82 \\
\hline & - & & 22.80 & 18.76 & 1.91 & 1.56 & 4.25 \\
\hline SEM & & & 0.59 & 0.28 & 0.19 & 0.08 & 0.26 \\
\hline \multicolumn{8}{|l|}{ Interaction effect } \\
\hline L-thr × SC & & $P$ value & $<0.05$ & $>0.05$ & $<0.05$ & $<0.05$ & $<0.05$ \\
\hline
\end{tabular}

${ }^{1}$ Relative to body weight. 
Use of L-threonine in the broiler diets improved the growth rate in the current study. However, dietary L-threonine and SC had no effect on carcass characteristics. Kidd et al. (2002) demonstrated that the formulation of diets to contain up to $544 \mathrm{~g}$ of L-threonine/ton did not affect growth or carcass attributes of commercial broilers. Rosa et al. (2001) found the threonine requirement of the classic strain broiler chick to be $0.69 \%$ for body weight gain and $0.68 \%$ for feed conversion ratio. Use of L-threonine decreased the crude protein requirements of the birds and reduced dietary crude protein which will improve nitrogen efficiency

Table 4 Effects of dietary Saccharomyces cerevisiae (SC) and L-threonine on intestinal morphology of broilers

\begin{tabular}{|c|c|c|c|c|c|c|c|c|}
\hline \multirow{2}{*}{\multicolumn{2}{|c|}{ Treatment }} & & \multicolumn{6}{|c|}{ Parameters } \\
\hline & & & \multicolumn{3}{|c|}{ Jejunum } & \multicolumn{3}{|c|}{ Ileum } \\
\hline L-threonine (g/kg) & SC & & $\mathrm{VH}^{1}$ & $\mathrm{VW}^{2}$ & $\mathrm{CD}^{3}$ & VH & VW & CD \\
\hline 0 & & & $1183^{\mathrm{b}}$ & $143^{\mathrm{b}}$ & $193^{\mathrm{c}}$ & $837^{\mathrm{b}}$ & $147^{\mathrm{b}}$ & $146^{\mathrm{b}}$ \\
\hline 2.5 & & & $1203^{\mathrm{b}}$ & $144^{\mathrm{ab}}$ & $202^{\mathrm{bc}}$ & $870^{\mathrm{b}}$ & $152^{\mathrm{a}}$ & $158^{\mathrm{ab}}$ \\
\hline 5 & & & $1226^{\mathrm{ab}}$ & $148^{\mathrm{a}}$ & $210^{\mathrm{ab}}$ & $875^{\mathrm{b}}$ & $151^{\mathrm{ab}}$ & $165^{\mathrm{a}}$ \\
\hline 7.5 & & & $1272^{\mathrm{a}}$ & $148^{\mathrm{a}}$ & $213^{\mathrm{a}}$ & $939^{\mathrm{a}}$ & $153^{\mathrm{a}}$ & $166^{\mathrm{a}}$ \\
\hline \multirow[t]{3}{*}{ SEM } & & & 25.33 & 0.67 & 1.67 & 31.52 & 2.27 & 2.34 \\
\hline & + & & 1232 & 145 & 207 & 913 & 151 & 163 \\
\hline & - & & 1209 & 146 & 202 & 837 & 152 & 154 \\
\hline SEM & & & 17.93 & 1.42 & 3.56 & 22.31 & 1.60 & 4.90 \\
\hline \multicolumn{9}{|l|}{ Interaction effect } \\
\hline L-thr $\times$ SC & & $P$ value & $>0.05$ & $>0.05$ & $>0.05$ & $>0.05$ & $<0.05$ & $>0.05$ \\
\hline
\end{tabular}

Table 5 Effects of dietary Saccharomyces cerevisiae (SC) and L-threonine on cell blood count (CBC) parameters and antibody titre against Newcastle disease in broilers

\begin{tabular}{|c|c|c|c|c|c|c|c|c|c|}
\hline \multirow{2}{*}{\multicolumn{2}{|c|}{ Treatment }} & & \multicolumn{7}{|c|}{ Parameters } \\
\hline & & & \multicolumn{5}{|c|}{ Cell blood count } & \multicolumn{2}{|c|}{ Antibody titres } \\
\hline $\begin{array}{c}\text { L-threonine } \\
(\mathrm{g} / \mathrm{kg})\end{array}$ & SC & & $\mathrm{WBC}^{1}$ & $\mathrm{RBC}^{2}$ & $\mathrm{Hb}^{3}$ & $\mathrm{HCT}^{4}$ & $\mathrm{MCH}^{5}$ & Day 26 & Day 42 \\
\hline 0 & & & 25.66 & 2.73 & 9.78 & 29.91 & 35.71 & 0.416 & 3.16 \\
\hline 2.5 & & & 25.25 & 2.68 & 9.58 & 29.13 & 35.33 & 1.000 & 3.66 \\
\hline 7 & & & 26.25 & 2.65 & 9.58 & 29.51 & 36.17 & 0.416 & 4.58 \\
\hline 7.5 & & & 25.97 & 2.73 & 9.45 & 29.31 & 34.75 & 0.666 & 5.41 \\
\hline SEM & & & 0.55 & 0.05 & 0.29 & 0.76 & 0.87 & 0.33 & 0.42 \\
\hline & + & & 26.12 & 2.66 & 9.32 & 28.70 & 34.88 & 0.666 & 4.41 \\
\hline & - & & 25.45 & 2.73 & 9.87 & 30.24 & 36.10 & 0.583 & 4.00 \\
\hline SEM & & & 0.39 & 0.04 & 0.20 & 0.53 & 0.62 & 0.234 & 0.29 \\
\hline \multicolumn{10}{|c|}{ Interaction effect } \\
\hline L-thr x SC & & $P$ value & $<0.05$ & $>0.05$ & $>0.05$ & $>0.05$ & $>0.05$ & $<0.05$ & $>0.05$ \\
\hline
\end{tabular}


utilization, reduce nitrogen excretion, improve poultry tolerance to high ambient temperatures and reduce the level of ammonia in litter (Kidd \& Kerr, 1996). Dozier et al. (2000) reported that an increase in the concentrations of the dietary threonine to $0.74 \%$ optimized live performance of male broilers. The extensive involvement of threonine in the intestinal mucosa and digestive enzymes may be related to its influence on AMEn and growth performance (Dozier et al., 2001). These findings are in agreement with our results in the current experiment. Supplementation of SC had no negative effect on the growth performance in the present study. Some authors reported that diets supplemented with yeast (S. cerevisiae) cell-wall components, can improve the growth performance of chickens (Karaoglu \& Durdag, 2005; Zhang et al., 2005). It might be due to the fact that SC decreased the colonization by Escherichia coli and increased Lactobacilli in the chicken gut (Sun \& Li, 2001). Several studies demonstrated that SC improved the efficacy of the immune system, improved intestinal lumen health, and increased digestion and absorption of nutrients, which resulted in better performance (Dozier et al., 2001; Kidd et al., 2002).

Results of the current study indicated that dietary L-threonine improved the intestinal morphology of the broilers. However, SC did not influence their intestinal morphology. Mucus consists of high molecular weight glycoproteins and it is known to contain a large proportion of this protein (Carlsted et al., 1993). Because threonine is highly concentrated in proteins directly associated with the gastrointestinal mucosa, as well as digestive enzymes in the lumen necessary for effective nutrient recovery, diets low in threonine may adversely affect the efficiency of nutrient recovery (Dozier et al., 2001).

Blood cell counts and antibody titres against Newcastle disease of broilers were not affected by the dietary treatments in the present study. However, dietary L-threonine increased the antibody titre at 42 days of age. These findings are consistent with results of Kidd et al. (1997) who reported that no differences in cellular immunity, humoral immunity or mortality were observed when broilers were fed an L-threonine supplement. In contrast, Bhargava et al. (1971) reported that the use of L-threonine ( $0.3 \%$ to $1.1 \%$ of diet) in chick diets increased the hemagglutination titres against Newcastle disease.

\section{Conclusions}

In conclusion, the supplementation of L-threonine as a source of threonine in combination with SC improved growth performance and intestinal morphology in broilers. However, dietary treatments had no effect on other traits such as antibody titre and cell blood count in these classes of birds.

\section{Acknowledgements}

This study was supported by the Mazraeh Nemoneh Company of Gorgan, Gorgan, Iran.

\section{References}

Ahmadi, H. \& Golian, A., 2010. The integration of broiler chicken threonine responses data into neural network models. Poult. Sci. 89, 2535-2541.

Baylan, M., Canogullari, S., Ayasan, T. \& Sahin, A., 2006. Dietary threonine supplementation for improving growth performance and edible carcass parts in Japanese quails, Coturnix coturnix Japonica. Int. J. Poult. Sci. 5 (7), 635-638.

Bhargava, K.K., Hanson, R.P. \& Sunde, M.L., 1971. Effects of threonine on growth and antibody production in chicks infected with Newcastle disease virus. Poult. Sci. 50, 710-713.

Carlstedt, I., Herrmann, A., Karlson, H., Sheehan, J., Fransson, L.A. \& Hansson, G.C., 1993. Characterization of different glycosylated domains from the insoluble mucin complex of rat small intestine. J. Biol. Chem. 268, 18771-18781.

Chen, K.L., Kho, W.L., You, S.H., Yeh, R.H., Tang, S.W. \& Hsieh, C.W., 2009. Effects of Bacillus subtilis var. natto and Saccharomyces cerevisiae mixed fermented feed on the enhanced growth performance of broilers. Poult. Sci. 88, 309-315.

Fuller, M.F., 1994. Amino acid requirements for maintenance of body protein accretion and reproduction in pigs. In: Amino Acids in Farm Animal Nutrition. CAB International, Wallingford, UK. pp. 155-184.

Grashorn, M.A., 2010. Use of phytobiotics in broiler nutrition- an alternative to infeed antibiotics. J. Anim. Feed Sci. 19, 338-347. 
Kanat, R. \& Calialar, S., 1996. A research on the comparison effect on broiler chickens performance of active dried yeast and inactivated and stabilized probiotic yeast supplemented to the rations in different levels. Poult. Sci. 75 (Suppl. 1), 123. (Abstr).

Kidd, M.T. \& Kerr, B.J., 1996. L-threonine for poultry: A review. J. Appl. Poult. Res. 5, 358-367.

Kidd, M.T., Kerr, B.J. \& Anthony, N.B., 1997. Dietary interaction between lysine and threonine in broilers. Poult. Sci. 76, 608-614.

Kidd, M.T., Chamblee, D.W., Carden, M.L. \& Burnham, D.J., 2002. Broiler growth and carcass responses to diets containing L-threonine versus diets containing threonine from intact protein sources. J. Appl. Poult. Res. 11, 83-89.

Dozier, W.A., Moran, E.T. \& Kidd, M.T., 2000. Responses of fast- and slow-feathering male broilers to dietary threonine during 42 to 56 days of age. J. Appl. Poult. Res. 9, 460-467.

Dozier, W.A., Moran, E.T. \& Kidd, M.T., 2001. Male and female broiler responses to low and adequate threonine on nitrogen and energy balance. Poult. Sci. 80, 926-930.

NRC, 1994. Nutrient Requirements of Poultry (8th ed.). National Academy Press, Washington, D.C., USA.

Onifade, A.A., Odunsi, A.A., Babatunde, G.M., Olorede, B.R. \& Muma, E., 1999. Comparison of the supplemental effects of Saccharomyces cerevisiae and antibiotics in low-protein and high-fiber diets fed to broiler chicken. Arch. Anim. Nutr. 52, 29-39.

Rosa, A.P., Pesti, G.M., Edwards, H.M. \& Bakalli, R.I., 2001. Threonine requirements of different broiler genotypes. Poult. Sci. 80, 1710-1717.

SAS, 2001. Statistical Analysis Systems user's guide: Version 8.02 Edition. SAS Institute, Inc., Cary, N.C., USA.

Shan, A.S., Sterling, K.G., Pesti, G.M., Bakalli, R.I., Driver, G.P. \& Tejedor, A.A., 2003. The influence of temperature on the threonine and tryptophan requirements of young broiler chicks. Poult. Sci. 82, 1154-1162.

Sun, J.Y. \& Li, W.F., 2001. Preparation of mannanoligosaccharide from Saccharomyces cerevisiae and its effect on intestinal microflora in chicken. Zhejiang Daxue Xuebao Nongye Yu Shengming Kexueban. 27, 447-450.

Zhang, A.W., Lee, B.D., Lee, S.K., Lee, K.W., An, G.H., Song, K.B. \& Lee, C.H., 2005. Effects of yeast (Saccharomyces cerevisiae) cell components on growth performance, meat quality, and ileal mucosa development of broiler chicks. Poult. Sci. 84, 1015-1021. 